\title{
$\approx$
}

PLANNING MALAYSIA

Journal of the Malaysian Institute of Planners (2004) II, 51-68

\section{URBAN LAND USE CHANGE AND THE LANGAT BASIN ECOSYSTEM HEALTH}

\author{
Shaharudin Idrus \\ Abdul Samad Hadi \\ Institute for Environment and Development (LESTARI) \\ UNIVERSITI KEBANGSAAN MALAYSIA (UKM)
}

\begin{abstract}
The paper discusses over four decades of urban land use changes in the Langat River Basin in response to rapid development impulses that flowed from the more developed Klang Valley where Kuala Lumpur, the Malaysian capital city is situated. It proceeds to look into the impact of those changes on the ecosystem health of the basin. Federal development policies, strategies, programs and activities have transformed the basin from an industrial agricultural basin into an urbanized area. Being contiguous to the Klang Valley, the basin rose over the decades to be a choice location for not only foreign direct investment to produce manufactured products for export but also services and educational. The paper also discusses the status of the Langat Basin ecosystem health. The change to the land use has indeed impacted on the basin ecosystem health. Using GIS, land use changes in the basin over the decades were analysed to reveal the persistent direction of change. It is clear that the trend of land use change in the Langat Basin is the conversion from one type of land use to developing urbanised and full urban areas. What is implied by the changes are indicators that can be derived to show the sustainability of the ecosystem in the Langat Basin such as river flood, mud flood, land slide, etc.
\end{abstract}

Key words: Langat River Basin, Ecosystem Health, Land Use, GIS,

\section{INTRODUCTION}

This paper perceives that economic, social and administrative driving forces have impacted on the Langat Basin land use. Land uses change continually from 1970 to 2001 that in turn impact on the basin ecosystem health. The ecosystem health concept is defined and impacts of the land use change will be summerised. Though far from clear, the ecosystem health is still a useful integrating concept to bring together man, culture and the environment. In this paper, land use is used as an illustration to discuss the status of the Langat Basin ecosystem health. 


\section{ISSUES RELATED TO LAND USE CHANGE}

\section{Meaning of Land Use}

At the outset, land use change needs to be clarified. "Land use involves both the manner in which the biophysical attributes of the land are manipulated and the intent underlying that manipulation - the purpose for which the land is used" (Turner et al. 1995, 20). In a similar vein, Meyer (1995) states that "land use is the way in which, and the purpose for which, human beings employ the land and its resources (Meyer 1995, 25 cited in Moser 1996, 247). Briefly, land use "denotes the human employment of land" (Turner and Meyer 1994, 5). Skole (1994) expands further and states that "Land use itself is the human employment of a land-cover type, the means by which human activity appropriates the results of net primary production (NPP) as determined by a complex of socio-economic factors" (Skole 1994, 438). Finally, FAO (1995) states that "land use concerns the function or purpose for which the land is used by the local human population and can be defined as the human activities which are directly related to land, making use of its resources or having an impact on them" (FAO 1995, 21).

The description of land use, at a given spatial level and for a given area, usually involves specifying the mix of land use types, the particular pattern of these land use types, the area extent and intensity of use associated with each type and the land tenure status (Bourne 1982, Skole 1994). More detailed natural and physical characteristics are recorded for each land use type for a complete description of land use (see, for example, Chapin and Kaiser 1979 for the case of urban land use studies; Meyer and Turner 1994 for regional and higher level studies).

However, both in the case of land cover as well as of land use, the meaning and conceptualization of change is much broader. In the case of land cover change, the relevant literature distinguishes between two types of change: conversion and modification (Turner et al. 1995, 22; Skole 1994, 438). Land cover conversion involves a change from one cover type to another. Land cover modification involves alterations of structure or function without a wholesale change from one type to another; it could involve changes in productivity, biomass, or phenology (Skole 1994, 438). Land cover changes are the results of natural processes such as climatic variations, volcanic eruptions, changes in river channels or the sea level, etc. However, most of the land cover changes of the present and the recent past are due to human actions - i.e. to uses of land for production or settlement (Turner et al. 1995, 27). More specifically, Meyer and Turner (1996) suggest that "Land use (both deliberately and inadvertently) 
alters land cover in three ways: converting the land cover, or changing it to a qualitatively different state; modifying it, or quantitatively changing its condition without full conversion; and maintaining it in its condition against natural agents of change" (Meyer and Turner 1996, 238).

Similarly, land use change may involve either (a) conversion from one type of use to another - i.e. changes in the mix and pattern of land uses in an area or (b) modification of a certain type of land use. Modification of a particular land use may involve changes in the intensity of this use as well as alterations of its characteristic qualities/attributes - such as changes from low-income to highincome residential areas (the buildings remaining physically and quantitatively unaltered), changes of suburban forests from their natural state to recreation uses (the area of land staying unchanged), and so on. In the case of agricultural land use, Jones and Clark (1997) provide a qualitative typology of land use changes: intensification, extensification, marginalization, and abandonment (Jones and Clark 1997, 26-27).

The magnitude of land use change varies with time period being examined as well as with the geographical area. Population change is used as a proxy measure of changes in the area of human settlements especially in urban areas. These latter changes are difficult to assess unambiguously as they are haunted by definitional and data problems (Douglas 1994). The impacts of these environmental problems are serious both in the short and in the long term. In the short term, food security, human vulnerability, health and safety are at stake; in the longer term, the viability of earth is being threatened.

Land use change is driven by a variety of forces, which relate differently to one another in different spatial and temporal settings. Holistic theories of land use change need to draw on a variety of theories relating to the drivers of this change, first, to offer realistic and meaningful accounts of land use change, second, to provide rigorous theoretical bases for modeling this change, and, third, to guide action in problem solving (i.e. planning) situations. More importantly, however, this blending and synthesising of theories - if it is ever achieved - may dissolve the present thematic boundaries (industrial change, spatial change, institutional change, etc.) and reveal a unified theory, a metatheory of change.

\section{Meaning of Ecosystem Health}

As land use change will affect an ecosystem health, there is need to explore the concepts of the ecosystem health in some details. The term ecosystem health has been hotly debated in the literature (Jamieson, 1995; Lackey, 1995; 
Rapport, 1995a; Wicklum and Davies, 1995; Callicott and Mumford, 1997; Simberloff, 1998; Rapport, 1995a,b) defines the states of the ecosystem health as the absence of signs of ecosystem distress, an ecosystem's ability to recover with speed and completeness (resilience), and/or a lack of risks or threats pressuring the ecosystem composition, structure, and/or function.

\footnotetext{
"Ecosystem health is the state of dynamic equilibrium between producers and consumers ensuring the optimum livelihood of all inhabitants in the unit. Human well-being should be a part of the harmony between all the other living beings in the ecosystem. The health concept should not be based solely on human health alone; otherwise, it will infringe on the life of other inhabitants of the ecology."
}

There is now evidence that many human dominated ecosystems, including various biophysical systems at regional and global levels, have become highly stressed and dysfunctional (Vitousek et al., 1997). The services provided by these ecosystems such as maintenance of ground and surface water supplies, balance of atmospheric gasses and reduction soil erosion etc. are extremely important to human welfare, but now they are losing, step by step. So fostering the practice of ecosystem health has never been more critical than at the present time. Ecosystem health is a major organizing paradigm for protecting and sustaining the quality of the environment and our own well-being, also as the foundational concept for developing new ways of assessing and managing environmental resources. Though concepts and theories related to ecosystem health approach are rapidly emerging, practical examples of the utility and result of this approach are critically important in understanding its application to real-life issues. Ecosystem health is not meant to be prescriptive in terms of method; the approach is as much a way of thinking as a precise way of doing things. However, owing to the complexity of ecosystems, it is not an easy task to find suitable ecological indicators to measure ecosystem health (Xu et al., 1999). Many researchers have proposed different definitions (Rapport, 1989; Norton, 1991; Costanza, 1992; Ulanowicz, 1992) and various indicators (Costanza, 1992; Jorgensen, 1995a,b). Costanza (1992) proposed an overall ecosystem health index. HI $=V \times O \times R$. Where $V$ is system vigor index, $O$ is the system organization index; and $R$ is the resilience index. Plainly, different indicators cover different aspects of ecosystem health. It may be necessary to apply several indicators simultaneously to get a sufficient image of the health or integrity of an ecosystem (Jorgensen, 1997).

In a word, as an integrative organizing principle, ecosystem health goes far beyond the boundaries of stress ecology, a field that concerns itself with the strictly biophysical aspects of the problem. It explicitly takes into account the wider territory of socioeconomic, human health, legal, and policy aspects. Of course, no one model can be expected to accomplish all of these goals at once, 
but practical evaluations of changes in ecosystem health must draw upon all of these dimensions (Rapport, 1995).

In this article we use the ecosystem health to show the current status of the ecosystem, measured from the changes in land use especially in urban area. This article shows that the ecosystem health is a useful integrative concept.

\section{URBAN LAND USE CHANGE IN THE LANGAT BASIN 1974 - 2001}

Urban land use change is to illustrate the use of ecosystem health in the Langat Basin. Developed/urban areas showed tremendous changes from the 1970s. Data from Table 1 highlighted the changes of developed areas/urban areas. In 1974 the developed areas (urban areas) size areas were calculated at 7,022.79 ha or $2.34 \%$, which then increased to $28,194.24$ ha or $8.77 \%$ in 1988 remaining the same in 1991 at $28,510.70$ ha or $8.86 \%$. In 1996 developed/urban areas increased to $30,968.31$ ha or $9.55 \%$ and then increased tremendously to $51,502.80$ ha or $14.94 \%$ of the entire Basin in 2001. It can be seen that the major changes in Langat Basin were the growth of urban areas, which caused a major impact to the natural ecosystem. In 1974, urban areas stood at 2,009.97 ha or $0.69 \%$, which then increased to $3,670.56$ ha or $1.25 \%$ in 1981 . This trend shows rapid growth in 1996 based on land cover classifications using Landsat TM, with urban areas increasing rapidly from about $21,007.85$ ha to $23,017.80$ ha in 1996 and further increasing $17,621.40$ ha to $40,639.20$ ha or $13.86 \%$ of the total land use in 2000 . This increased doubled within five years, and almost 20 times of the figures in 1974.

The Langat Basin ecosystem has and is undergoing rapid changes. In the 1960s and 1970 s much of its original lowland dipterocarp and peat swamp forests were lost through conversion to agricultural plantations, tin mining areas and human settlements (Wong, 1974). More recently, its natural areas have come under increasing pressure from rapid urbanization and industrialization, particularly the development of the administrative centre, Putrajaya which was given the status of Federal Territory, the development of Cyberjaya to link with the Multimedia Super Corridor that stretches from Kuala Lumpur, and the zoning of new industrial areas which has since overtaken agricultural activities. This has given rise to employment opportunities and infrastructure development, hence the rapid growth in urbanisation and industrial development. 
The land use change from 1996 to 2001 is interesting to analyse due to the development of new administrative centre located at Putrajaya (formerly known as Prang Besar) and Cyber Jaya. In 1996, the agricultural activities shown decline from $176,640.00$ to $164,841.00$ hectares in 2001 , while the shrubland showing to increase from $7,950.51$ to $10,863.60$ hectares and developed areas increase tremendously from $23,017.80$ in 1996 to $40,639.20$ hectares in 2001. The changes from agricultural to developed area will give an impact to ecology and socio-economic of the basin and Selangor as a whole.

The conversion from one land use to another type of land use give different impacts to the ecosystem. The focus of this paper is on the conversion from other type of land use to the developed area or bareland/shrubland that believed will caused the higher negative impact to the ecosystem such as mud flood, land slide, etc. Within three decades, the changes from agriculture area to developed areas were the highest changes $(295,026,300$ hectare) compared to the other conversions. The reasons behind this changes was the availability of the agriculture land and suitable to be developed for urban areas. The peat swamp and mangrove areas especially in Kuala Langat district also converted to the developed areas such as housing estates and industrial area. The development of the Putrajaya and Cyber Jaya in Sepang district shows the higher changes from agriculture to developed area.

\section{Driving Forces to the Langat Basin Land Use Changes}

Land use changes and trends of that change in the Langat Basin were directed and influenced by, policies and strategies legislated by Federal and State Governments. There are also other factors that influence the land use changes in the Basin such as the process of urbanization. The Federal and State governments see globalisation as a challenge to enable Malaysia competes at the global level. The Langat Basin has been chosen as one of the major areas for economic growth as well as preparing for urbanization. This is true as Kuala Lumpur International Airport, West Port, the MSC and Putrajaya are located in the Basin. These infrastructure and facilities have been developed to attract foreign investors and thereby building capacity to compete at global level in terms of trade and technology development. Land use changes in the Langat Basin is significantly influenced by policies legislated by the Federal and State Governments. The New Economic Policy and the successive Malaysian five year plans have been the key policies and with strategies and programs that drive the land use patterns in the basin. 
TABLE 1:

Land use/Land cover Change in Langat Basin 1974-2001 in hectares

\begin{tabular}{|c|c|c|c|c|c|c|c|c|c|c|c|c|}
\hline & 1974 & $\%$ & 1981 & $\%$ & 1988 & $\%$ & 1991 & $\%$ & 1996 & $\%$ & 2001 & $\%$ \\
\hline FOREST & 127831.3 & 43.57 & 121509.39 & 41.42 & 88920.96 & 30.32 & 87652.44 & 29.89 & 80571.22 & 27.47 & 70702.63 & 24.11 \\
\hline $\begin{array}{l}\text { Hill } \\
\text { Dipterocarp }\end{array}$ & $46,822.6$ & 15.96 & $45,966.80$ & 15.67 & $46,566.30$ & 15.88 & $49,097.40$ & 16.74 & 47643.10 & 16.24 & 43864.10 & 14.96 \\
\hline Peat swamp & $46,603.2$ & 15.89 & $43,879.90$ & 14.96 & $20,190.00$ & 6.88 & $17,542.40$ & 5.98 & 12571.90 & 4.29 & 7894.53 & 2.69 \\
\hline $\begin{array}{l}\text { Lowland } \\
\text { Dipterocarp }\end{array}$ & $5,757.10$ & 1.96 & $4,563.99$ & 1.56 & $2,372.13$ & 0.81 & $1,809.54$ & 0.62 & 1514.52 & 0.52 & 1207.80 & 0.41 \\
\hline Mangrove & $28,648.4$ & 9.77 & $27,098.70$ & 9.24 & $19,792.53$ & 6.75 & $19,203.10$ & 6.55 & 18841.70 & 6.42 & 17736.20 & 6.05 \\
\hline $\begin{array}{l}\text { DEVELOPED } \\
\text { AREA }\end{array}$ & 7022.79 & 2.34 & 7601.49 & 2.53 & 28194,42 & 8.77 & 28510.70 & 8.86 & 30968.31 & 9.55 & 51502.80 & 14.94 \\
\hline Shrubland & $5,012.82$ & 1.71 & $3,930.93$ & 1.34 & $6,658.92$ & 2.27 & $10,312.70$ & 3.52 & 7950.51 & 2.71 & 10863.60 & 3.70 \\
\hline $\begin{array}{l}\text { Developed } \\
\text { Area }\end{array}$ & $2,009.97$ & 0.69 & $3,670.56$ & 1.25 & $21,535.50$ & 7.34 & $18,198.00$ & 6.21 & 23017.80 & 7.85 & 40639.20 & 13.86 \\
\hline $\begin{array}{l}\text { AGRICULTU } \\
\text { RE }\end{array}$ & & 52.92 & & 54.79 & & 57.97 & & 58.21 & & 60.22 & & 56.21 \\
\hline Agriculture & 155,249 & 52.92 & $160,733.0$ & 54.79 & $170,016.0$ & 57.97 & $170,705.0$ & 58.21 & 176640.0 & 60.22 & 164841.0 & 56.21 \\
\hline WATER & & & & & & & & & & 1.75 & & 2.12 \\
\hline Water Bodies & $3,267.27$ & 1.11 & $3,496.59$ & 1.19 & $6,170,13$ & 2.10 & $6,401.52$ & 2.18 & 5132.52 & 1.75 & 6207.12 & 2.12 \\
\hline TOTAL AREA & 293370.36 & 100.0 & 293340.47 & 100.0 & 293301.51 & 100.0 & 293269.66 & 100.0 & 293312.05 & 100.0 & 293253 & 100.0 \\
\hline
\end{tabular}

Source: Shaharudin et. al 2004 


\section{New Economic Policy (1970 - 1990) and the Five Year Malaysian Plans}

The First Malaysia Plan was introduced in 1966 for the country's planning from 1966 to 1970 . This was a continuation from the two previous Malayan Plans, which were introduced after Independence in 1957. The first three plans focused upon the administrative and financial aspects for the structuring of a newly independent country. However, after the racial riots in 1969, the government had begun to realise that economic planning was to be explicitly based on social criteria. Its emphasis was on:

'Rapid socio-economic development, in which all Malaysians have the opportunity, the right, and the responsibility to participate and share equitability and embark upon a long-term development strategy designed to meet the overriding need for national unity' (Malaysia, 197.3).

Thus, with this, the New Economic Policy (NEP) was introduced in 1970 and incorporated into the Second Malaysia Plan (RMK2) (1971 - 1975). The NEP is felt to have been the major driving force of land use changes in Malaysia (Sulong and Katiman Rostam, 1987). This policy, which was introduced in mid1970 's had two main objectives, the eradication of poverty regardless of race, and the restructuring of the Malaysian society so as to reduce the identification of employment with race and location within the context of an expanding economy (Malaysia, 1973). Therefore, the formulation and adoption of regional development was used as a strategy for national development to reduce disparities between regions. The emphasis from purely sectoral based planning in earlier plans was changed to comprehensive regional planning as a mean for economic development. This is to ensure that a balance is achieved between rural development and urban development efforts.

In Second Malaysian Plan, under NEP, Outline Perspective Plan (OPP), urban and regional planning development policies were introduced. These policies were necessary to drive development in rural and other growth centres. These decentralisation and integrated rural development began to take shape in Banting, Telok Panglima Garang, Nilai, Batu 9 and Batu 11 Cheras, Kajang and Semenyih. Agriculture activities were identified to raise income levels and to create a dynamic economic and social environment for rural areas (Malaysia, 1973). RMK2 focused on the acceleration of the expansion and modernisation of the agricultural sectors and employment opportunities, extensive land development and improvement. This can be seen through the government's efforts in establishing agricultural institutions at the state and Federal level such as FELDA, FELCRA, RRI and MARDI. This is to provide a more effective channel for marketing services, credit and research results, to farmers in order to 
increase productivity and make them more commercially viable. The intensification of agricultural activities paid off as this sector provided about one half of the total employment, with 96,000 jobs and land development contributing about 65,000 jobs.

However, the Third Malaysia Plan's (RMK3) (1976-1980) regional development had played a greater role in the formation of national development. Its objectives were to redress economic and structural imbalance among the regions within the country and ensuring that regional development contributes towards the national goals for economic development. The NEP was used to accelerate rate of growth of less developed regions, exploit full potential of human and physical resources of these areas, and ensure an equitable distribution of basic services and amenities. Thus, the need to develop existing urban centres and establish new townships to achieve these objectives began. RMK 3 also emphasized on industrial development, particularly in less developed states (Malaysia 1979) and still continuing focus on agricultural development.

The decade of the 1970s and 1980s was a period of implementation of NEP. At the same time the emphasis was given to industrialization in Malaysia. The factors influencing the changes of land use and land cover are:

a) Industrial urbanisation which brought large numbers of rural youths to the urban areas, working in factory environments.

b) Increased public sector workforce opening up access to urbanisation for the rural population

The Third Malaysia Plan was a landmark in national development policy which opened up a floodgate of opportunities for rural population. Selangor state embarked on a large scale development plan attempting not only to guide but to change the path of development - that consciously included rural population in its development agenda. It was during this period that the mass urbanisation took place. For the first time job opportunities in the form of new factory employment became available. The state also increased its public services jobs, attracting number of rural population to urban fringe areas.

\section{National Urbanisation Policy}

Until today there has been no comprehensive and official policy on urbanisation perse. However, strategies and approaches use in order to achieve the NEP objectives, urban development can and have been considered as an urbanisation policy. This policy promotes the development growth centres that are arranged in a network of high-density urban centres, with different types of township in 
terms of size and roles. To achieve these objectives, strategies have been planned and identified as follows:

a. To assure balanced urban development in term of physical development, ethnic participation and efficient resources management.

b. To enhance urbanisation process in rural areas through participation of land development scheme settlers and community in-situ in urban economic activities as well as small industrial activities.

c. To assure well planned development in existing urban growth centres, taking into account of local requirements. Structure plan for main centres and local plan for smaller growth centres have been prepared. These plans should serve as guidance for development and to enhance efficiency of development plans in urban areas.

d. To introduce the concept of urbanising the rural areas through aggregating adjacent small villages to become small towns or rural development centres, where the industries, business and commercial agriculture could be put in place.

In support of this and to assure that development of the existing towns and growth centres are well structured, the government introduced the "Structure Plan" and "Local Plan" through the Town and Country Planning Act 1976. The entire districts of the Basin's towns and the Multimedia Super Corridor (MSC) have their own structure plans and local plans.

Moreover these concepts were the basis for the physical planning stage, which were used for zoning and dividing areas for each land use category. These were supported by guidelines as follows:

i. Development Planning Report (LPP) guidelines.

ii. Housing guidelines.

iii. Commercial guidelines.

iv. Industry guidelines.

v. Hill Area Development guidelines

vi. Local Area Development Plan.

The new township strategy was adopted, as it was concomitant with the development of industrial estates to provide social and urban facilities such as housing, essential services and various amenities for industrial workers and their dependant). Areas such as the District of HuIu Langat were earmarked to 
be the newly developed areas or towns. Through this strategy, the town of Kajang in HuIu Langat grew rapidly to meet the demand for urban services arising from increasing rural wealth due to the upturn in development and supported the spill over from the Klang Valley.

\section{National Industrial Policy}

Since 1970's the government has emphasized on the development and growth of industrial sector for sustaining economic growth and creating job to achieve the NEP objectives. However, these industries were export-oriented and used large number of workers. In the 1980's, the government started a program which encouraged the development of heavy industries. This was to boost the industrial development and to assure the sustainability of economic growth as well as to increase the country's capability to compete at the global level. Therefore, in 1986 The National Industrial Policy (NIP) was put in place to show the government efforts towards industrialisation. NIP enhanced the industrialisation process and helped the industrial sector becoming the main engine for Malaysian economic and national growth. The objectives of the industrial policy were:

a. To make the manufacturing industry sector as the catalyst of national industrialisation development.

b. To encourage full utilisation of national natural resources.

c. To enhance local technology research and development (R\&D) as the basis to develop Malaysia as industrialised country.

To achieve these objectives strategies and plans had been identified. The Industrial Master Plan, (IMP) and IMP2 were the main documents used to drive the development of industry in Malaysia.

In terms of land use change in the Langat Basin, the industrialisation policy and its strategies focused on that enhanced existing industrial areas and developed new industrial estates in areas with the required infrastructures such as highways, roads and utilities. This strategy helped to reduce cost of development of industrial estates. Until 1997, this strategy had opened 30 industrial estates in the Langat Basin. With the modernisation of the industrial sector and the government's effort to diversify the existing industries towards developing high tech and information technology industries, more industrial estates were to be developed. The MSC was to play the major role for this industry, and it will have a significant impact to the Langat Basin in the future. 
Global multinational corporations turned to the rural areas for workers resulting in commuting and firming specific urbanisation. Rural gentrification where rural population composition shifted to a higher urban based population residing in rural areas whereby;

a) Role of state and its repositioning within the context of Multi National Cooperation (MNC)

b) Reaction and response by the people - involvement and distancing

c) The macro to micro perspective

d) A study on how people negotiate space

From the information gained in the study of land use and land cover pattern changes, it is apparent that the primary driving forces are economic and sociopolitical development in the country that affects the Basin. While spatial sciences would place elements such as distance and accessibility, as well as agglomeration and other locational variables as crucial, the role of the government (and with it the social driving forces) cannot be downplayed. Literature in development studies have identified that the patterns of development in Southeast Asia as being led and initiated, rather than a private sector endeavour supported or approved by the state (Hoogvelt, 1977). The case in point is the development of Cyberjaya, Kuala Lumpur International Airport (KLIA) and the Federal Territory of Putrajaya. This also includes the Multimedia Super Corridor (MSC), a 15 kilometer by 50 kilometer area stretching from Putrajaya to the Kuala Lumpur city centre specifically at the KLIA in Sepang. In visiting the early parts of the MSC, Cyberjaya what is apparent is a very subdued vision of development. Single storey resort style developments belie its targeted goal. Passing through the oil palm plantation reveals a way to the digital black gold (the investors wish), the site for the headquarters of the Multimedia Development Corporation, built in less than five months depicting a resort style living. Visually, it seems to fit the surroundings, though the feeling of an amphitheatre is felt, but the clearing of the jungle is clear. There are elements of the Indonesian and the Japanese architecture and landscaping, but the suitability to the surrounding is questionable.

After the official launching of KLIA, Putrajaya and Cyberjaya, the entire MSC project took off, and is expected to create impacts unrivalled before in the Langat Basin. KLIA, the new international airport sits on a 25,000 acre parcel spanning two mukims, Labu and Sepang has created an access hub in what were previously plantations. Putrajaya, the new federal administrative centre proposed as early as 1993 on a 10,847 acres land in Mukim Dengkil has now transformed the area into a post-modern complex of government agencies, and soon-to-be-completed housing projects. 
Together with the Cyberjaya intelligent city project, these efforts are capable of turning the entire region into a new city - as was attempted in Brasilia, during a much earlier time. Being identified as the hub of computer and multimedia technology, the structure plan projected some 570,000 population for the whole Structure Plan area 250,000 are expected to be within Putrajaya, another 240,000 in the incorporated area and the remaining 80,000 on Malay reserve lands (Anon, 1995). The Structure Plan also envisioned 127,000 jobs to be generated with 76,000 from the public sector and 58,900 from the private sector. Much of this perhaps will be jobs diverting from existing areas. It is also estimated that about 116,000 units of housing will be required to house the new population. To add to this expected boom is the development of nearby Airport City at Bandar Baru Salak Tinggi, targeted not only to take over from Sepang as the District Administrative Centre but also as an urban centre with industries and new institutions.

Apart from this, the Sepang Formula 1 Circuit built four years ago, adjacent to KLIA, very much active, has had a strong impact on the environment, particularly to the land use and land cover change, and to the people in the Langat Basin. Other development projects expected to impact on the Langat Basin ecosystem include;

a) The development of the central link highway connecting Kuala Lumpur with KLIA and the KL-Seremban highway.

b) The Development of the South Kelang Valley highway

c) The proposed highway between Kuala Lumpur, Putrajaya and KLIA.

d) The development of the Express Rail Link connecting Kuala Lumpur, Putrajaya and KLIA.

e) The connecting system for the Light Rail Transit between Bukit Jalil and Putrajaya. The proposed coastal alternative route for Klang Bukit Kemandul - Sepang - Lukut - Port Dickson - Tanjung Agas Linggi - Melaka. The Bukit Nanas, Port Dickson waste disposal site.

The other primary driving force for land use change is the strong growth of construction industry in the early 1990s, which was linked to the urbanisation process, which up to the economic downturn of the late 80's and 90's had a major influence on driving investors to look for developable land. The Langat Basin, previously an agricultural region, provided the much needed asset. Conducive government policies and support of construction projects allowed the fast conversion of agricultural land. 


\section{Implications of Land Cover Change to the Langat Basin Ecosystem Health}

The reason for looking at urban growth as an ecosystem process is that the physical environment either man-made or natural is part of the elements that make up the urban scene. The intrinsic as well as the stated definition of urbanization and development thus takes into consideration the well being, growth and 'welfare' of the environment. By making environment as part of the equation defining the advancement of urbanization, the process of urbanization itself cannot be separated from the working of the environment. In this manner, environment cannot be totally static and neither can urbanization be void of environmental concerns. There is then needs to be a redefinition of environmental and urbanization concerns. Questions are then placed on more established ideas of conservationism and preservationism. It will also develop new challenges for ideas of environmental ethics which in the Malaysian case may differ from current Western ideas. Within the context of urban growth as an ecosystem process, one can then evaluate the imbalance within the system, and prepare plans for future sustainable urbanization.

Among the more evident problems created by unbalanced rapid urban growth which will have impacts on the quality of urban life and ecosystem are:

- Proliferation of squatter settlements

- Housing and sanitation

- Traffic congestion

- Environment quality

- Unemployment and underemployment

- Social and moral crisis; the rise of counter-culture

- Urban without urban

- Poverty and marginal groups

The relationship between man and nature for the past thousands years has created and impacted on the society itself. The stresses that exist as a product from the relationship can be shown by multidimensional evident such as flood, mud flood, landslide, criminal cases, drugs, and vector-borne disease such as dengue, cholera, asthma cases and others. In the Langat Basin, the evidents are taken as manifestation of the stress that is experienced by the society. The vector-bourne diseases were found at Hulu Langat district (Shaharudin Idrus et. al, 2000); the asthma cases in places closed to the Klang Valley (Shaharudin and Mazrura, 2000). All showing the consequences of the land use changes in the basin. 
With regards to the above issues which emanate from urban growth, priority on policies on urban management should be given due consideration with particular emphasis on housing, traffic congestion, environmental quality (water, air and noise), and local participation in managing the urbanization process. Certainly all these negativities are problematic. But the urban areas in the basin can still sustain themselves. More people are attracted to come and stay to earn their living. From this point of view, the ecosystem health of the basin is still in good shape, well above the tolerant level of the urbanites. In short, from basin life sustenance view, the basin is healthy.

\section{CONCLUSION}

The changes of urban land use in Langat Basin for the past four decades shows the conversion from other type of land use to the urban land use which cannot be converted to the original land use in turn. The changes have generated much negativity to the people in the basin. Yet those negativities should not be interpreted as a downward trend to the basin ecosystem health. In sum, the basin is still attractive to industries, allied activities and people. At any time, one sector may be under stress but at other times it may revert to its former stature following ameliorative action of the administrative action. The ecosystem health concept is a useful integrating concept to bring together man, culture and the environment.

\section{REFERENCES}

Bourne, L.S., ed. 1982. Internal Structure of the City: Readings on Urban Form, Growth, and Policy. $2^{\text {nd }}$ edition. Oxford: Oxford University Press.

Chapin, F., S. Jr. and E.J. Kaiser. 1979. Urban Land Use Planning. Urbana: University of Illinois Press.

Callicott, J.B., Mumford, K., 1997. Ecological sustainability as a conservation concept. Conservation Biology 11, 32-40.

Costanza, R., 1992. Toward an operational definition of health. In: Costanza, R., Norton, B., Haskell, B.D. (Eds.), Ecosystem Health-New Goals for Environmental Management. Inland Press, Washington, DC, 239-256.

Costanza, R., 1995. Ecological and economic system health and social decision making. In: Rapport, D.J., Calow, P., Gauder, C. (Eds.), Evaluating and Monitoring the Health of Large-Scale Ecosystems. Spring-Verlag, New York, pp. 103-126. 
Food and Agriculture Organization (FAO). 1995. Planning for Sustainable Use of Land Resources. FAO Land and Water Bulletin 2. Rome: Food and Agriculture Organization of the United Nations.

Douglas, I. 1994. Human Settlements. In Changes in Land Use and Land Cover: A Global Perspective, eds. W.B. Meyer and B.L. Turner II, 149-170. Cambridge: Cambridge University Press.

Hoogvelt, A., 1997. Globalisation and the Post Colonial World, Baltimore: John Hopkins University Press

Jamieson, D., 1995. Ecosystem health: some preventative medicine. Environmental Values 4, 333-344.

Jones, A. and J. Clark. 1997. Driving Forces behind European Land Use Change: An Overview. In The User Needs for More Harmonized Land Use Information at the National and EU Level. Report on the CLAUDE workshop, Wageningen, The Netherlands, 22-23 May, 1997. CLAUDE (Coordinating Land Use and Cover Data and Analyses in Europe), Concerted Action, EC, DGXII, pp. 24-31.

Jorgensen, S.E., 1992. Parameters, ecological constraints and exergy. Ecol. Model. 62, 163-170.

Jorgensen, S.E., 1995a. Exergy and ecological buffer capacities as measures of ecosystem health. Ecosyst. Health 1 (3), 150-160.

Jorgensen, S.E., 1995b. The application of ecological indicators to assess the ecological condition of a lake. Lakes Reservoirs: Res. Manage. 1, 177182.

Jorgensen, S.E., 1997. Integration of Ecosystem Theories: A Pattern, vol. 2. Kluwer, Dordrecht, 400

Lackey, R.T., 1995. Ecosystem health, biological diversity, and sustainable development: research that makes a difference. Renewable Resources Journal 13, 8-13.

Malaysia 1973. Third Malaysian Plan 1976 - 1980. Percetakan Nasional. Kuala Lumpur

Malaysia 1979. Fourth Malaysian Plan 1980-1984. Percetakan Nasional. Kuala Lumpur

Mazrura Sahani, Shaharudin Idrus, Azman Mohamed and Norzila Mohd Zain. 2002. Integrating Childhood Asthma Surveillance and Land Use Patterns Using Geographical Information Systems (GIS). Malaysia Journal of Public Health Medicine. Volume 2 (Supplement 1). ISSN: 1675-0306

Moser, S.C. 1996. "A Partial Instructional Module on Global and Regional Land Use/Cover Change: Assessing the Data and Searching for General Relationships." Geojournal 39(3): 241-283.

Norton, B.G., 1991. Toward Unity Among Environmentalists. Oxford University Press, New York. 
Rapport, D.J., 1989. What constitutes ecosystem health? Perspect. Biol. Med. $33,120-132$.

Rapport, D.J., 1992. Evaluating ecosystem health. J. Aquat. Ecosyst. Health 1, $15-24$.

Rapport, D.J., 1995. Ecosystem health: more than a metaphor? Environ. Values 4, 287-309.

Rapport, D.J., Costanza, R., McMichael, A.J., 1998. Assessing ecosystem health. Trends. Ecol. Evol. 13 (10), 397-402.

Schaeffer, D.J., Herricks, E.E., Kerster, H.W., 1988. Ecosystem health:1. Measuring ecosystem health. Environ. Manage. 12, 445-455.

Shaharudin Idrus, Shamsul Azhar Shah, Tahir Aris, 2001. Analisis Reruang

Dalam Kajian Demam Denggi di Bandar Baru Bangi dan Kajang Menggunakan Sistem Maklumat Geografi (GIS). Kertas Kerja Yang Dibentangkan di Seminar Geoinformation 2001, Hotel Berjaya Georgetown, Pulau Pinang, 12 \& 13 November 2001

Shaharudin Idrus, Abdul Hadi Harman Shah and Ahmad Fariz Mohamed. 2004. Land use change in Langat Basin. In Mazlin Mokhtar, Shaharudin Idrus and Sarah Aziz Abdul Ghani. Proceedings Of The 2003 Langat Basin Ecosystem Research Symposium. Penerbit LESTARI, UKM

Simberloff, D., 1998. Flagships, umbrellas, and keystones: is single species management passe in the landscape era. Biological Conservation 83, 247257.

Sulong Mohamed and Katiman Rostam 1987. Matlamat dan Arah Pembangunan Bandar Baru di Malaysia: Pengalaman Bandar Baru Bangi, Selangor. In Pembangunan di Malaysia: Perencanaan, Perlaksanaan dan Prestasi. Kuala Lumpur Persatuan Sains Sosial Malaysia.

Skole, D.L. 1994. Data on Global Land-Cover Change: Acquisition, Assessment, and Analysis. In Changes in Land Use and Land Cover: A Global Perspective, eds. W.B. Meyer and B.L. Turner II, 437-471. Cambridge: Cambridge University Press.

Turner, B.L. II and B.L. Meyer. 1994. Global Land Use and Land Cover Change: An Overview. In Changes in Land Use and Land Cover: A Global Perspective, eds. W.B. Meyer and B.L. Turner II, 3-10. Cambridge

Turner, B.L. II, D. Skole, S. Sanderson, G. Fischer, L. Fresco, and R. Leemans. 1995. Land-Use and Land-Cover Change; Science/Research Plan. IGBP Report No.35, HDP Report No.7. IGBP and HDP, Stockholm and Geneva.

Ulanowicz, R.E., 1992. Ecosystem health and trophic flow networks. In: Costanza, R., Norton, B., Haskell, B.D. (Eds.), Ecosystem Health-New Goals for Environmental Management. Inland Press, Washington, DC, pp. 190-206. 
Vitousek, P.M., Mooney, H.A., Lubchenco, J., Melillo, J.M., 1997. Human domination of earth's ecosystems. Science 227, 494-499.

Wicklum, D., Davies, R.W., 1995. Ecosystem health and integrity. Can. J. Bot. 73, 997-1000.

Wong. K.H. 1974. Landuse in Malaysia. Kuala Lumpur. Ministry of Agriculture

Xu, F.-L., Jorgensen, S.E., Shu, T., 1999. Ecological indicators for assessing freshwater ecosystem health. Ecol. Model. 116, 77-106. 